\title{
Os crimes das multidões
}

\author{
"Ubi multitudo, ibi malum" - SÊnECA
}

\section{Luiz Fernandes Lima}

O tema que vamos abordar se refere a um tipo de estudo, que não tem preocupado muito os espíritos. As relativamente poucas obras, que temos encontrado, são demonstrativas do quase nulo interêsse que o assunto tem despertado. $\mathrm{Na}$ realidade, sòmente alguns autores, dentre êles, Sighele, Elias de Oliveira, Tarde, Le Bon, têm livros dedicados ao problema da multidão que delinque. Os demais afloram a questão, ao de leve, em capítulos perdidos na imensidão de seus tratados, sem trazerem, no entanto, nenhuma contribuição pessoal à solução do problema. Valem-se das idéias e das luzes dos principais expositores da matéria, e, tão só com isso, satisfazem-se. Foi essa circunstância que nos levou a abordar tal assunto, a par da consciência de que as multidões delinquentes merecem ser estudadas com mais carinho, uma vez que, hoje em dia, em virtude das condições do meio ambiente social, com facilidade surge, num relâmpago, o grupo multitudinário, disposto a tudo, a matar, a depredar bem como a aclamar e aplaudir. A formação de classes trabalhadoras como a dos bancários, dos comerciários, dos industriários, com suas sub-classes, tecelões, metalúrgicos, gráficos, etc., e a constituição dos respectivos sindicatos, como que favorece a rápida organização de coletividades. $\mathrm{O}$ homem toma consciência do seu "eu individual" e do seu "eu social", digamos antes, do seu "eu de classe". Sabe que pertence a 
determinado agrupamento; assume como que tácita obrigação moral de participar dêsse conglomerado de seus pares e quando quer que chamado a comparecer para integrá-lo, desloca-se de onde estiver, atendendo a êsse imperativo de ordem moral. Reina soberana, hoje em dia, a idéia que só a multidão poderá obter aquilo que nem sempre é desejado individualmente: a reinvidicação de classe. Os comícios, arvorados em panacéia de todos os males sociais, proliferaram de tal forma, que a própria lei não pôde desconhecê-los, consagrando-os, inclusive, nossa Carta Magna (art. $141 \S \mathrm{XI}$ ).

Não é nosso objetivo, absolutamente, criticar esta situação, dizendo se é um bem ou mal. Fazemos tais observações, sòmente para constatar um fato que existe e que não pode ser negado. O que, todavia, nos permitimos é afirmar que a multidão é um caldo de cultura onde o germe do mal prolifera e se desenvolve com rapidez espantosa; onde duzentas, quinhentas, mil pessoas podem pensar e agir como uma só pessoa; onde uma simples descarga basta para eletrizar a turba e fazê-la mais ou menos dócil e obediente ao capricho de uma voz que a orienta e a dirige; uma voz que pode elevá-la aos píncaros do heroismo, bem como precipitá-la no abismo do crime. "A multidão é um terreno em que o micróbio do mal se desenvolve fàcilmente ao passo que o micróbio do bem morre quase sempre à míngua de encontrar condições de vida." (Sighele, A Multidão Criminosa, pág. 58).

A tomada de consciência do trabalhador dêsse "eu de classe" favorece a composição imediata de multidões, mais ou menos definidas, com suas peculiaridades psicológicas, suas idiossincrasias e notas determinantes. Poderíamos dizer, embora pareçamos paradoxais ou confusos, que êsse fenômeno - "eu de classe" — permite a formação de "multidões-individuais", ou seja, desnecessário se torna que o indivíduo esteja reunido física e corporalmente a seus pares; pode estar sòzinho, isolado de todos e ainda assim agirá da mesma maneira coma atuaria se estivesse em 
meio à turba enlouquecida, embora a distância do foco atenúe os efeitos da infecção.

Está êle prêso ao mesmo liame psicológico que o torna submisso à vontade do "meneur". A influência dêste atua à distância atingindo exatamente aquêle indivíduo, dentre outros, para conformá-lo a determinada atitude. Embora à distância, as impressões que a multidão classista recebe, são decalcadas no processo psicológico daquele que se considera participante da mesma, ainda que fìsicamente dela não faça parte.

O progresso, significando especialização, vai, cada vez mais intensamente, diversificando as multidões classistas, transformando-as em unidades autônomas, com feições psicológicas próprias, imprimindo-lhes tendências definidas. Hoje em dia, dessarte, há grande facilidade de os homens se reunirem em multidão, facilidade erigida inclusive, em garantia constitucional; por outro lado a turba apresenta fecundidade extrema em conceber, no seu ventre, o germe do crime. Não vá nisso nenhum exagêro: nem tôda multidão delinque, mas tôda multidão é condição para a prática dos crimes, cujas raizes procuraremos investigar.

Ėste estudo não acalenta, nem de longe, a pretensão de esgotar o assunto. A matéria, sôbre ser vasta, é controvertida porque objeto de ciência ainda recente. A psicologia coletiva, capítulo da psicologia geral, iniciou-se pràticamente nos fins do século passado e albôres do atual. Não atingiu, portanto, ainda, aquela maturidade cientifica em que determinados conceitos são inconcussos e estaqueiam arcabouço garantidor de pesquisas laterais. Quem se proponha a estudar a psicologia das coletividades terá de abrir com os meios que dispuser, uma picada no matagal do desconhecido. Face tais dificuldades, nós, a quem falta mór profundidade de indispensáveis conhecimentos de psicologia geral bem como de sociologia, e ainda êsse pioneirismo de desbravadores, limitar-nos-emos a seguir o caminho aberto por outros, procurando trazer 
à tona o que os estudiosos dessa matéria têm de comum, aceitando ou criticando, na medida em que fôrmos capazes de fazê-lo, as idéias de cada um, o que afinal vem ser a característica dêste trabalho: compilação, embora parcial e fragmentária, do que sôbre o assunto se escreveu. Por outro lado, atendendo às exigências do curso a que esta tese se refere, limitar-nos-emos ao estudo da multidão que delinque, deixando de lado quaisquer outros aspectos da psicologia coletiva, que, apesar de interessantes, não se conformariam à feição do trabalho.

A imitação, tão magistralmente descrita por — TARDE em seu livro "Les Lois de l'Imitation", explica em parte porque uma multidão, apesar da heterogeneidade de seus componentes, heterogeneidade de nacionalidade, de sexos, idades, caracteres, etc., se transforma em um só corpo, animado de uma só vontade, tendendo para determinado alvo comum.

A imitação, tendência nata do homem, revestindo as formas de imitação-moda, imitação-simpatia, imitaçãoobediência, imitação-educação, etc., destrói a originalidade, esmaece as diferenças, equipara os desníveis, uniformiza os caracteres.

Êste instinto tão atuante no homem isolado, atinge o paroxismo de seu poder nos homens reunidos em multidão. BordiER em seu livro "La Vie des Societès", 1808, pag. 76, afirma que - "chaque homme est individuellement disposé à l'imitation, mais cette faculté atteint son maximum chez les hommes assemblés."

A imitação encontra guarida em tôdas as formas de vida e convivência humanas: o filho imita o pai; os fracos, os poderosos; os povos a outros povos. Verifica-se a imitação, na arte, na literatura, nos crimes, nos suicídios. Um 
indivíduo que não pintasse imitando a natureza, por certo não seria compreendido e sua obra seria estéril. Objetar-me-eis com a arte moderna, em que os quadros são inúmeras vezes incompreensíveis, mas nem por isso deixam de ser considerados obras de arte. No entanto, eu vos direi: Ide a uma exposição de quadros dessa natureza e em vez de apreciá-los, contemplai os que a visitam e vereis todos os tipos de máscara humana, menos a de compreensão, e, sobretudo, a de riso. A tendência do homem médio é repudiar essas manifestações de arte, que êle não compreende, que não the fazem sentido. Por outro lado, os chamados pintores modernistas também não estão sendo originais: são imitadores de outros; imitam, em última análise, um primeiro que teve a "originalidade" de pintar uma tela dêsse tipo. Aliás, Max Nordau, em seus "ParaDoxos", já dissera que: "A originalidade não é outra coisa que a primeira representação da vulgaridade"

A psicanálise, com a teoria dos complexos, nos diz que a criança passa tôda a sua infância e puberdade imitando o pai ou a mãe, introjetando ol super-ego dos maiores em seu aparelho mental; mais tarde é a influência dos mestres, das pessoas a quem o adolescente admira, enfim, da sociedade. O super-ego vai evolvendo, recebendo influências ora de um, ora de outro modêlo; o super-ego vai se diferenciando através da imitação de modêlos vários, até tornar-se cada vez mais impessoal. Portanto, a criança herda um super-ego, pelo processo de identificação, herança essa constituida de inúmeros legados.

Deixamos de nos referir à imitação nos crimes e nos suicidios, em que determinadas formas de matar ou ferir atingem, em certas ocasiões, os fôros de moda. Haja vista a vitriolagem, o assassínio a revolver, por mulheres abandonadas. Tivemos há poucos anos, no Rio de Janeiro, a epidemia de maridos assassinados pelas esposas. Em São Paulo, a onda de latrocínios contra motoristas de táxis; a vaza alarmante de crimes de fundo sexual que assombrou 
a cidade. Quanto ao suicídio, a história do lorde inglês que se atirou no Vesúvio, seguido logo depois, por inúmeros conterrâneos. Narra Sighele que 15 inválidos se enforcaram sucessivamente, num curtíssimo espaço de tempo, num gancho que havia no corredor escuro de um edifício. (A Multidão Criminosa, pág. 39).

Êsse instinto imitativo, que tão fortemente atua sôbre os indivíduos isolados, cresce de poder na medida do número de pessoas. Quanto maior o agrupamento humano, ınais poderosamente influi a imitação. A emoção experimentada por um irradia-se imediatamente para o grupo; as almas trepidam ao sabor do mesmo vendaval psicológico; o raciocínio obnubila-se; a razão é sobrepujada pelos sentimentos; a vaga multidinária escalda na fornalha das emoções e a multidão, enfraquecida a capacidade raciocinante, cega a razão, é joguete do ódio, do amor, da ira, do ardor patriótico. E é neste momento que se cria a chamada "alma coletiva" das multidões. Aquêle conglomerado heterogêneo homogeniza-se; aquela massa inorgânica organiza-se. Aplainam-se as diferenças, equiparam-se os desníveis, desbastam-se as arestas: eis a multidão psicológica! Multidão psicológica que se não confunde com os agregados humanos em que nada liga seus membros. Gustave Le Bon em sua "Psicologia das Multidões", pág. 12, nos afirma que "Em certas ocasiões, meia duzia de homens podem constituir multidão psicológica, ao passo que centenas de homens casualmente reunidos, podem não constituí-la". É preciso, para que surja a multidão organizada ou psicológica, uma identificação de seus elementos integrantes, através da imitação. Só assim é que se poderão observar aquêles caracteres de que os escritores que tratam do assunto nos dão notícia; a grande impulsividade de que as multidões são donas, atirando-se, conforme as excitações, diante da morte, sem estremecer, ou recuando pusilânimes face um perigo aparente; a mobilidade, que a faz experimentar tôda a gama dos sentimentos desde o desprendimento generoso até a crueldade requintada; $a$ : 
irritabilidade que a faz um animal perigoso, onde a menor palavra mal interpretada ferirá seus brios profundamente excitados e a tornará capaz de matar; por outro lado não se esqueça sua credulidade, onde não existe o inverossímel e os maiores absurdos e mentiras são considerados possiveis e verdades concretas, exatamente porque sua função raciocinante está obliterada: o exagero e a simplicidade dos sentimentos das multidões, que vai logo às do cabo quer no ódio, quer no amor. LE BoN tem palavras exatas para descrever isto: (pág. 36). "A simplicidade e o exagêro dos sentimentos das multidões fazem com que estas não conheçam dúvidas nem incertezas. Como as mulheres, vão sem hesitar até às últimas extremidades; uma suspeita, apenas enunciada, transforma-se imediatamente em indiscutível evidência; um começo de antipatia ou de reprovação que no indivíduo isolado se não acentuaria, torna-se imediatamente em ódio feroz no indivíduo em multidão". Padecem ainda as multidões de intolerância que bem se pode resumir nestas palavras: quem não está a meu favor, está contra mim. São ainda autoritárias, principalmente porque, embora de modo inconsciente, têm noção de sua fôrça e poder. Não admitem a menor dúvida sôbre o que lhes pareça, no momento, certo ou errado. É fácil verificar-se êste característico, numa reunião pública em que, se um orador rebate pontos aceitos como inconcussos para a multidão, é imediatamente interrompido por vaias, assobios, uivos que poderão degenerar em massacre físico à pessoa do orador, se êste insiste em suas palavras, fazendo por desconhecer a irritabilidade do aglomerado psicológico.

Esta é a multidão psicológica; êste é o monstro de mil braços e de um só cérebro; esta é a turba que poderá delinquir!

No entanto, não nos basta saber como surge a multidão organizada. Apontamos a imitação como a fôrça catalítica que combina as partes do todo multitudinário. Necessitamos, agora, indagar como atua a imitação. 
Várias respostas foram formuladas a esta questão. Entenderam alguns estudiosos que a imitação se transmitia por contágio moral. O indivíduo imitaria, uma vez contagiado, da mesma maneira que alguém adquiriria tuberculose, contaminando-se. Transcrevemos estas palavras de Joly, colhidas em Sighele ( $A$ Multidão Criminosa, pág. $37 / 38$ ) porque são altamente elucidativas do que seja o contágio moral: "A imitação é um verdadeiro contágio que tem o seu princípio no exemplo, como a varíola tem o seu contágio no virus que a transmite; e do mesmo modo que existem na nossa organização, doenças que só esperam para se desenvolverem a mais ligeira causa, assim também há em nós paixões que permanecem mudas no exercício da razão e que podem despertar ùnicamente por efeito da imitação".

Com Jolly, estão de acôrdo outros estudiosos como Despine, Moureau de Tours, Ebrard, etc. (Apud Sighele).

No entanto, isto não nos satisfaz. Sabemos que a doença se chama imitação e aceitamos, com êsses autores, que ela é contagiosa. Mas, não vai aí grande mérito. A própria idéia de imitação implica na afirmativa de seu contágio. Não concebemos imitação que não seja contagiosa. Os dois têrmos dessa equação, para nós, são equivalentes. Portanto, cremos que a idéia de contágio moral não veio acrescentar nada ao que sabíamos. Usando de uma imagem imperfeita, mas que esclarece perfeitamente nosso pensamento, diríamos que a idéia de "imitação" está para a de "contágio", assim como a idéia de "viagem" para a de "locomoção". Não se pode falar em viagem sem se dizer, implìcitamente, que houve uma locomoção, mudança de um lugar para outro. São palavras de idêntico conteúdo ideológico. No entanto, o que está implícito na idéia de locomoção e que não foi dito é que o viajante se serviu de alguma coisa para locomover-se: trem, automóvel, avião. Isto, quando tratamos da imitação, é que verdadei- 
ramente interessa indagar. De quê maneira se propaga a imitação? Como atua seu poder contagiante?

Cremos que TARde e Sergi responderam completamente a estas interrogações. A sugestão é a responsável pelo poder contagiante da imitação. O veículo, o meio de locomoção da doença imitativa, é a sugestão.

Segundo Sergi (Psicosi Epidemica) e Tarde (Qu'est ce qu'une société?), a sugestão é um fenômeno físico-orgânico. Qualquer tecido orgânico atua sòmente através dos estímulos externos recebidos. Um músculo se contrái, se estimulado. Uma idéia é sugerida pela visão de algo externo; um som provoca imagens mentais a êle relacionadas em algum tempo e lugar. Uma palavra irritada nos provoca igual reação irada. Enfim, a sugestão é o estímulo externo que provoca um reflexo idêntico sôbre aquilo que atua. Por outro lado, varia o grau de receptividade entre as pessoas: uns são fàcilmente influenciáveis, outros com mais dificuldade; no entanto, ninguém se pode furtar à sugestão. Dentre os ràpidamente sugestionáveis poderiamos apontar os emotivos, os menores, os loucos. Nos primeiros, em que há preponderância da afetividade, as sugestões não censuradas pela razão, que é sobrepujada com frequência pelos sentimentos, provocam imediatos reflexos emotivos. Os menores, em que o fortalecimento da personalidade, entendida esta como conjunto de idéias próprias e definidas, está ainda se verificando, a sugestão torna-os presa fácil dos sentimentos. Nos loucos, os desvios de inteligência e razão possibilitam o incremento súbito das influências externas. Por outro lado deve se notar que a sugestão é fenômeno ambivalente. Recebida a impressão, esta é devolvida ampliada ou não, conforme a capacidade receptiva e reflexiva de cada um, indo influenciar aquêle que primeiro a emitiu. Entre os indivíduos normais e isolados, a reflexão é fraca porque as emoções recebidas são censuradas pela razão; quando, porém, se trata de emotivos, menores e loucos, êstes, pelo predomínio da afe- 
tividade, têm tendências para devolver amplificadas as sugestões recebidas. Nêstes, às vêzes, um estímulo insignificante poderá provocar uma reação exagerada.

Bosquejados sucintamente os característicos da sugestão entre os indivíduos isolados, podemos passar aos indivíduos reunidos em multidão. Nêstes, a sugestão atua mais rápida e poderosamente. $\mathrm{E}$ isto pelas seguintes causas: a influência do número, a natureza dos membros, a proximidade dos elementos, o nível cultural dos componentes do grupo.

$\mathrm{O}$ número de indivíduos tem grande importância se atentarmos para o que acima dissemos: a ambivalência da sugestão. Todo indivíduo é ao mesmo tempo receptor e emissor de impressões. Por outro lado encontram-se na multidão, caracterizada pela heterogeneidade, aquêles "re. -eminentes amplificadores" (permití-me o termo) que exageram a emoção recebida. Suponhamos uma multidão de 500 pessoas. Cada um de seus membros receberá não só a sugestão daquele que a dirige, como também sofrerá a influência do reflexo das sugestões recebidas pelos outros 499 partícipes. Portanto, a sugestão não será equivalente a 1, mas a 499. O número permite o aumento surpreendente e desmesurado da sugestão. Por outro lado, a proximidade dos elementos, permite uma aceleração no processo de recepção e emissão. Os indivíduos se influenciam uns aos outros instantâneamente. Não devemos esquecer, também, o fator intelectual dos indivíduos agregados em massa. $O$ indivíduo inculto é mais sugestionável que o culto. Este, pelo maior desenvolvimento da inteligência, tem uma vida afetiva regrada. No entanto, como já fizemos sentir, a formação da chamada alma coletiva oblitera a capacidade racionante, equiparando os desniveis intelectuais, fazendo a sentimentalidade sobrepujar a razão, pelo que o homem culto que, isolado, seria fracamente sugestionável, quando em multidão se torna mais fácil vítima dos sentimentos. 
Estudada a formação da multidão psicológica, contudo não respondemos ainda a esta pergunta de capital importância: Porque delinque a multidão? Será suficiente que um indivíduo veja outro matar alguém, para que também se ponha a agir da mesma maneira? A sugestão provocada por palavras que induzem ao crime, ou pela prática de atos delituosos basta para que o sugestionado se ponha a delinquir? Cremos que não.

Alguns autores, como Sauvergne e Barbaste, entenderam que deveriamos atribuir os crimes da multidão a uma espécie de furor instintivo, a uma disposição homicida primordial. Atribuem, portanto, a responsabilidade dos delitos coletivos sòmente ao fator antropológico. Di Tullio caracteriza de maneira um tanto diferente êste elemento: "consideramos que, mais que uma específica disposição homicida, seja oportuno admitir em todo indivíduo a existência de uma disposição instintiva genérica para a agressividade, a qual, sob a influência de estímulos excepcionais, tende a acentuar-se em uma disposição à violência, que, em alguns casos, pode ser também causa de homicídios", (pág. 274 - "Tratado de Antropologia Criminal”, ed. espanhola 1950). Esta é parte da verdade, mas não é a verdade inteira. Além dos fatôres antropológicos, podemos responsabilizar também os fatôres sociológicos.

O mesmo Benigno Di Tullio, em seu "Tratado de Antropologia Criminal”, (versão espanhola, pág. 273) acrescenta: "Entre os fatôres sociais que mais frequentemente influem em tal sentido, devem ser lembrados, antes de mais nada, os desastres econômicos, as lutas político-sociais, a desordem moral".

Com efeito, a situação de instabilidade econômica que atravessamos, a insatisfação com os govêrnos, a decadência dos costumes vão tornando o povo descontente, egoista, preocupado ùnicamente com seu bem estar individual, desconhecendo e não se apiedando das mazelas de seus pares. É um "salve-se quem puder", tanto mais cruel porque im- 
posto pelas contingências. Vai desaparecendo aquela fraternidade e comunhão de idéias altruísticas, aquela submissão prazeirosa aos poderes constituídos. A lei, feita para protejer os homens, torna-se instrumento de coação de uns poucos guindados às alturas. Procura-se violá-la impunemente, de todos os modos, crentes que exatamente para isso foi ela criada. $O$ povo se sente espoliado, iludido, ludibriado, joguete de seus mandatários. $O$ sentimento de revolta vai se enraizando, deitando tronco, enfolhando, derramando frutos e sementes. A onda de descontentamento e insatisfação vai arrebatando tudo e todos. A isto, aliando-se aquêle crescente poderio das massas, aquela tomada de consciência do "eu de classe", o reconhecimento de que são uma fôrça social, que dificilmente encontrará diques que se lhe oponham, tudo isto combinado poderá dar uma reação, cujos efeitos serão imprevisiveis, mas indubitàvelmente, quaisquer que sejam, serão violentos.

Formada a multidão psicológica em que se pode apontar como característica a alma coletiva, temos o caldo de cultura onde vicejará o germe do mal. Atuando os fatôres antropológicos ou biológicos e os sociais, temos a multidão preparada para o crime. No entanto, só isto é insuficiente. A multidão, nêste momento, é potencialmente criminosa, mas ainda não delinquiu. Acha-se à fração de centímetro da beira do abismo, mas ainda não se precipitou. Nêste instante é que entra em cena o fator "ocasião". Parodiando aquele dito popular - "a ocasião faz o ladrão", diríamos - "a ocasião faz a multidão". E assim é: aquela turba, estimulada até o frenesi, enervada por tốdas as paixões que escondia no sub-consciente e que afloraram à tona, espera sòmente um gesto, uma palavra que lhe dê determinada forma e a precipite em determinada direção, como uma enxurrada dantesca. A importância dos "meneurs" avulta neste momento. Dêle depende, na maioria das vêzes, o tornar-se a multidão um pugilo de heróis, ou uma fera assassina. No entanto, saliente-se que às vêzes 
a turba consegue subtrair-se a sua influência e operar contra a vontade dêle. Aquela mole humana não conhece meio têrmo e é como uma parêlha de cavalos fogosos contra a qual o pulso do cocheiro luta inùtilmente para moderar a velocidade desenfreada, antevendo o abismo que os animais, no furor da disparada, não reparam, indo nele precipitar-se irremediàvelmente.

A ocasião, representada por uma palavra, um gesto significativo, dará as diretrizes do comportamento da turba. Os livros que tratam do assunto relatam inúmeros casos em que o fator ocasião foi o principal responsável por acontecimentos lamentáveis.

Se assim é, se o comportamento do grupo multitudinário depende da ocasião, parece que fica invalidada aquela observação que colhemos em SigHele de que, na multidão, o micróbio do mal se desenvolve com mais facilidade que o do bem. Todavia, isto não acontece porque é indiscutível que as mais das vêzes a ocasião é má do que boa. E Sighele salienta com maestria o caracteristico ativo da maldade e o passivismo da bondade. Esta é humilde, tímida, quase sempre escondendo-se, quando não, manifestando-se numa atitude negativa: não fazer o mal; ao passo que aquela se caracteriza quase sempre por uma ação. E demonstrado ficou que a formação da turba psicológica depende da imitação e da sugestão. Ora imitam-se movimentos, atos, gestos, palavras com muitíssimo maior rapidez que atitudes passivas ou negativas. Sendo a maldade muito mais ativa que a bondade, é evidente que mais ràpidamente será imitada, levando-se, ainda, em conta a natural predisposição dos homens para o mal, produto do atavismo que a civilização mal consegue encobrir.

Assim sendo, não é de admirar-se que na maioria dos casos a multidão seja antes execrada que exaltada. Dificilmente os bons conseguirão furtar-se à influência deletéria do grupo e impôr seu ponto de vista. Aliás, ocorre aquilo que Sighele chamou de "mimetismo psíquico". 
Procuram os honestos adquirir a côr dos sentimentos do grupo, como uma auto-defesa, porque sabem que se se opuserem, serão esmagados inevitávelmente pela intolerância, pela arbitrariedade da multidão enfurecida.

Deixada de lado aquela predisposição do homem ao malefício, não se esqueça que a multidão é constituída quase sempre de uns poucos bons e honestos; o restante de suas alas é engrossado por vagabundos, criminosos, desiquilibrados, semi-loucos e psicopatas de tôda espécie. A contribuição das mulheres, que se encontrem fazendo parte do todo, é também decisiva para fazer inclinar a tendência da multidão para o mal. A literatura a respeito nos dá prova cabal de que o elemento feminino, quando enfurecido, é muito mais cruel que o masculino. A êste, pertence a brutalidade nua; àquele, os requintes da brutalidade.

Formada a alma coletiva, empolgadas as boas qualidades de uns poucos pelo enxurro maléfico de muitos, atuando os fatôres antropológicos e sociais, a multidão se precipita num emaranhado confuso e atordoante, derramando-se em desbordamentos que não há conter, praticando tôda a sorte de violências, desde atentados à propriedade, passando à gama dos crimes de perigo comum, até culminar em agressões físicas e delitos mais graves, como o homicídio. A malta enfurecida, rompidos os diques da censura individual e social, desborda, assim, em violações de vários setores do Código Penal. A Justiça estende seus braços, mas só consegue apanhar um ou outro náufrago do turbilhão multitudinário que trazido à flor da vaga espumante é lançado pela ressaca no banco dos réus. Reflui a onda ululante e aquêle destrôço mesquinho, só, cessado o tumulto, pode então avaliar, com horror, tôda a extensão do seu ato. Êle que, isoladamente, jamais teria infringido a lei penal, vê-se apontado como autor de crime atroz, que, devolvida a capacidade de raciocinio e de reflexão, se the apresenta como algo hediondo. Este homem que delinquiu 
em meio a uma multidão enlouquecida, que praticou um delito a que chamaremos - crime multitudinário -, como deverá ser punido? Sob que aspecto deverá ser encarado seu crime para que lhe seja atribuída uma punição justa?

\section{III}

O legislador penal brasileiro de 1940 entendeu que o crime multitudinário deveria gozar de alguma complacência e estabeleceu para êle a circunstância atenuante do art. 48, VI, "e": "São circunstâncias que sempre atenuam a pena: ter o agente cometido o crime sob a influência de multidão em tumulto, se, lícita a reunião, não pravocou o tumulto, nem é reincidente".

Subordina, assim, o código, o cabimento da atenuante a três requisitos: licitude da reunião; não ter o autor provocado o tumulto; não ser reincidente.

Seria esta a melhor solução, ou é passível de crítica a atitude do legislador?

Sighele, em seu "A Multidão Criminosa" (pág. 140), entende que os indivíduos que praticam crimes, sob influência da multidão, devem ser considerados semi-responsáveis, adotando em parte a teoria de PugliEse; no entanto, estabelece algumas restrições, pois acha que, se tal teoria fôsse aplicada integralmente, os criminosos natos que praticassem um crime multitudinário seriam considerados semi-responsáveis, o que segundo êle, é um absurdo. Aceitando a crítica que Garofalo lhe fêz ao livro "A Multidão Criminosa", Sighele acha que a pena deverá ser graduada conforme a gravidade objetiva do crime, mas atendendo também à periculosidacie de quem o cometeu.

Clovis Bevilaqua escreveu em "Criminologia e Direito, 1896, págs. 50/51", que a responsabilidade é menor nos dominados do que nos dominadores e deve ser limitada, observando-se certa gradação consistente na maior ou menor 
perda da individualização em meio ao torvelinho da multidão. Portanto, quanto mais houver adequação entre os objetivos criminosos da multidão e as idéias e tendências do individuo, maior será sua responsabilidade, porque a sugestão homicida não precisa atuar muito intensamente para predispor o indivíduo ao crime. Esta teoria não deixa de ser reflexo da de Sighele.

Evaristo dE Morais propõe duas soluções: a criação de uma figura criminal "sui generis" em que se comine pena menos grave relativamente àquela em que incorreria o indivíduo se praticasse a mesma ação delituosa individualmente; o outro alvitre é o de se estabelecer uma circunstância atenuante com forte poder atuante na minoração da pena (Apud E. DE Olrveira, págs. 296/297).

Por outro lado, Elias de Oliveira, no capítulo "Nova Penologia dos Crimes das Multidões”, págs. 373/405 de seu belo livro "Criminologia das Multidões", propõe a solução que entende melhor, consistente em considerar os delitos multitudinários sob o tríplice aspecto: dolosos, preterintencionais e culposos. Entende ser doloso o daquele indivíduo que, estando já disposto a praticar um delito, se incorpora à multidão para que, em meio a ela e por alguma influência dela, possa realizar seu intento. Preterintencional, quando a pessoa, revestido o elemento subjetivo de tôdas as características do dolo, pretenda um resultado menos lesivo do que o que se vem a realizar. Seria crime culposo aquêle da generalidade das infrações coletivas. $O$ indivíduo se incorpora ao agregado voluntàriamente, mas vém a praticar um delito por fôrça das conjunturas que apontamos neste trabalho. Recomenda ainda ELIAS DE Oliveira que se atente para os motivos determinantes do crime e a periculosidade criminal do autor da infração.

Parece-nos utópica a pretensão do citado monografista. Cremos ser impossível na prática verificar-se, com segurança, qual a natureza do elemento subjetivo do agente. A ser aceita a proposta do mesmo, correr-se-ia o risco, exatamente por causa dessa dificuldade, de se verem todos 
os delitos multitudınários considerados como culposos, o que viria contra a necessidade da justa retribuição penal. Acresce, ainda, a circunstância de que, se entendermos culposo um delito das multidões, será preciso admitir-se que o agente, ao praticar o ato delituoso, tinha suas faculdades mentais totalmente obliteradas por influência da multidão; estava "moralmente embriagado", na expressão dos autores que tratam do assunto. Se assim fôsse, seria êle irresponsável, pois tal embriaguês moral equivaleria, por exemplo, à alcoólica fortuita.

Em desacôrdo com a afirmação supra, tem-se aventado exemplo de delitos multitudinários em que é dito verificar-se a culpa "stricto sensu".

Assim numa greve de motoristas em que, saindo êles com seus carros, viessem eventualmente atropelar ou matar um transeunte, teríamos um delito multitudinário culposo.

Não nos parece admissível tal entendimento se atentarmos para o fato de que num crime culposo, o agente não quer o resultado. Mata por exemplo, "sem querer". No delito multitudinário, ao revés, o indivíduo "quer" praticar a infração. Mata, sabendo que mata e o faz voluntàriamente.

Portanto, temos para nós que o delito coletivo só pode ser doloso, quer seja determinado o dolo, quer indeterminado. $O$ indivíduo se incorpora voluntàriamente à multidão e quando, porventura, pratica um delito, o faz também voluntáriamente, embora se possa dizer que sua vontade foi destorcida e êle agiu em função da vontade coletiva ou de "meneur".

Tem-se comprovado que a influência sugestionadora não é tão irresistivel como pretendem alguns. Os caracteres diamantinos podem a ela se furtar mais ou menos incólumes. Onde ela atua de maneira arrebatadora e total é sôbre aquêles indivíduos com propensão ao mal. Se assim é, não fica invalidada a nossa tese de que o delito 
coletivo só pode ser doloso, porque, punindo-se êsses mesmos agentes a título de dolo, vem-se a reprimir uma tendência que cêdo ou tarde se manifestaria, na oportunidade de ambiente favorável. Este raciocínio é válido, ainda para aquêles casos em que não se pode falar claramente em predisposição criminosa, mas numa imaturidade mental, tomando esta expressão em seu sentido lato, abrangendo a orgânica e a patológica, como é o caso dos menores, emotivos e psicopatas. Não se quer dizer que não deva ocorrer, por exemplo, com o louco, aquela dirimente que normalmente é invocada em tais casos. O que se afirma é que o delito multitudinário não reveste intrìnsecamente as características de moléstia mental. A turba-multa alvoroçada está enlouquecida mas não é louca. "Não é certo que as paixões e as emoções da multidão excitada constituam uma forma de enfermidade mental. Êsses fatos, portanto, não valem como elementos de inimputabilidade ou de escusa "(Corte de Cassação de Roma) (Rev. Forense, v. 39, pág. 493) "Trata-se de um estado de exaltação ou sugestão coletiva, e não de enfermidade mental, ocorrendo, pois, a imputabilidade" (Rev. Forense, v. 37, pág. 377, C. Cass. Roma). O delito multitudinário puro, a rigor, deveria ser atribuído inteiramente à multidão, tomada esta como um sêr uno. Todos os partícipes do grupo deveriam ser responsabilizados por ato delituoso que qualquer dos membros praticasse, em função da atividade sugestionadora. No entanto, isto, sôbre ser impossivel na prática, acarretaria, pelo mesmo motivo, a necessidade de punição da sociedade, tôda vez que um de seus elementos delinquisse, porque modernamente se reconhece, não só no indivíduo como no meio, a existência das causas geradores dos crimes. Se na realidade não se pune o grupo social, embora gere êste causas de crimes, pelo mesmo motivo não podemos punir a multidão, apesar de se admitir que ela foi a causa do crime multitudinário. Este raciocínio nos leva obrigatòriamente a admitir uma punição atenuada para os crimes das multidões, uma vez que o fato delituoso foi praticado em 
virtude do meio. Para isso, cremos que a solução é uma circunstância atenuante que dê ao julgador a possibilidade de graduar a pena conforme a natureza de cada caso, levando em conta o maior ou menor gráu de sugestão que induziu o indivíduo ao delito, e tendo em vista, ainda, a periculosidade ou não do agente. Queremos deixar frisado que esta solução, que entendemos ser a melhor para o crime multitudinário, diz respeito àquela infração praticada por um individuo normal que isolado não delinquiria. Outras circunstâncias ocorrentes, como a menoridade, a loucura, etc. são deixadas de lado porque, na realidade, não pertencem à essência da penologia do delito coletivo, uma vez que são genéricas e, portanto, sempre levàdas em consideração.

Assim, concordamos com o legislador penal, quando estabelece a atenuante do art. 48 , IV, letra " $e$ ". O que nos parece digno de crítica é o fato de a mesma ser limitada sòmente aos delinquentes primários, e ainda desde que não tenham provocado o tumulto e seja lícita a reunião do grupo. Que seja reunião lícita é assunto e examinar-se. Parece-nos que o Código pretende dizer que a reunião deve ser não defesa em lei, deve ter fins lícitos. Roberto Lyra a págs. 345 vol. II dos Comentários ao Código Penal frisa que: "Quem toma parte em reuniões ilícitas já está fora da lei". A drasticidade desta afirmação poderá, às vêzes, ocasionar injustiças, porque não leva em consideração os adventícios que se reunem à multidão por curiosidade, arrastados pelo exemplo dos que se agrupam e são contagiados pela sugestão, despersonalizando-se no aglomerado, e agindo em função dêle, sem saber, as mais das vêzes, os fins primitivos da reunião. Note-se, também, a possibilidade de agregação de menores à turba, inconscientes da ilicitude da reunião. Ora, para êstes veda a lei se aplique a referida atenuante, o que nos parece injusto. Deveria, a nosso vêr, determinar o Código que o participante do grupo tivesse consciência da ilicitude da reunião para que, então, não Ihe assistisse a atenuante. 
Por outro lado, a privação, para o reincidente, dessa atenuante, levaria algumas vêzes a resultados injustos. Suponhamos, por exemplo, que o indivíduo tenha sido condenado por uma contravenção e depois pratique um crime multitudinário. Não seria excessiva punição o descabimento da atenuante para êle? Entendemos até que no caso se verifica infração ao princípio "non bis in idem", pois que o indivíduo perde o direito à atenuante, por causa da reincidência e, por outro lado, tem a pena exarcebada em virtude dessa mesma reincidência, que é uma agravante.

O Código não estendeu êsse benefício aos condutores. Cremos que aqui andou mais exato. Com efeito, os incitadores são indivíduos em geral mais perigosos que os "menés". Têm consciência do ato que praticam, embora, também, fiquem "embriagados" pelo vinho da multidão. Recebem os reflexos da sugestão que provocam e se deixam contaminar. Contudo, se isto é assim, ainda não se pode desconhecer que, de certa maneira, pretendiam o resultado que sobreveio. Se, às vêzes, a multidão vai além do que êles desejavam, não é de esquecer-se que, pelo menos, assumiram o risco de produzir aquêle resultado.

Isto posto, cremos que a seguinte redação da citada atenuante atenderia melhor aos fins que colima:

São circunstâncias que sempre atenuam a pena:

"e" - ter o agente cometido o crime sob a influência da multidão em tumulto se, lícita a reunião ou desconhecendo-lhe o caráter ilícito, não provocou o tumulto".

Dessa maneira, só não ocorre a atenuante para os "meneurs".

Para os reincidentes fica ao arbítrio do juiz a aplicação da atenuante, o que não gerará injustiça, ainda mais se atentarmos para a agravante da recidiva que lhe dá meios para uma retribuição mais adequada. 
Quanto à ressalva do desconhecimento da ilicitudade da reunião, poder-se-á dizer que tal alegação sempre será feita, abrindo-se dessarte uma válvula de escape. No entanto, obvia-se êste inconveniente através do exame das circunstâncias materiais que elucidarão perfeitamente o magistrado, o qual com cautela, julgará da veracidade da afirmação, e o perigo será removido. Em todo caso. se dúvida houver, deverá a atenuante ser abonada ao a que alega, pois sempre se dará relêvo àquela humana justificação: "In dubio pro reo". 